\title{
INCIDENCE OF NEUROSIS IN A NEW HOUSING ESTATE
}

\author{
BY \\ F. M. MARTIN*, J. H. F. BROTHERSTON*, AND S. P. W. CHAVE \\ From the Department of Public Health, London School of Hygiene and Tropical Medicine, University of London
}

A housing estate built by the London County
Council in Hertfordshire has provided the setting for
a series of socio-medical investigations carried out
by members of the Department of Public Health,
London School of Hygiene and Tropical Medicine.
Reports so far published include an analysis of
general practitioner consultations (Brotherston and
Chave, 1956), and a brief discussion of some social
and psychological effects of rehousing (Maule and
Martin, 1956). This paper presents an estimate of
the incidence of mental illness among the population
of the estate. In view of the estate's demographic
structure one would be led to expect a relatively low
rate of mental illness, since those groups with the
highest risk of admission to mental hospitals-
old people, unmarried adults, unskilled workers-
form a small part of the estate population (Brotherston and Chave, 1956). On the other hand, it seemed plausible that the strains consequent on rehousing in a new estate of suburban character, combined with the preponderance of small families unsupported by extended kinship ties, might predispose to an increased incidence of at any rate the minor psycho-neurotic and psycho-somatic disorders. We were also aware of the fact that, in an appreciable proportion of rehoused families, some degree of priority for rehousing had been allowed because of illness in one or another member of the family, with neurotic illness ranking fairly high among the conditions concerned, and we were interested to know how far this might have increased the need for psychiatric or quasi-psychiatric care. We were not in a position to undertake a direct screening of a representative sample of the estate population, and in the circumstances decided to obtain a number of simpler and necessarily more superficial indices of the incidence of mental illness. Three of these relate

- Now of the Department of Public Health and Social Medicine, University of Edinburgh. to the use of medical services and the fourth is based on self-assessment:

(1) Admissions to mental hospital in the period 1949-1954.

(2) Referrals to psychiatric Out-Patient Clinics in the period 1952-1954.

(3) General practitioner consultations associated with psychiatric or psycho-somatic diagnoses during 1953.

(4) Complaints of "nerves", “depression", etc., reported in the course of a direct interview survey carried out in 1954-1955.

\section{Mental Hospital Admissions}

Records of the admission of certified and voluntary patients to the mental hospitals serving the area are available from the beginning of 1949, that is to say, from about one year after the building of the estate was begun. From then until the end of 1954 there were 129 admissions of patients from addresses on the estate. Table I (opposite) shows the distribution of these cases year by year and relates them to the estimated population of the estate.

During the period when the estate was in course of construction the size of the population at risk was constantly changing. The figures given in Table I are mid-year estimates based on the records of the London County Council's Housing Department and checked where possible by reference to other sources, such as the 1951 Census and the results of our own field enquiries in 1953-55. There is no doubt that the overwhelming majority of cases needing in-patient psychiatric treatment were received at a single hospital in Hertfordshire, but we cannot, of course, preclude the possibility of admissions, especially of voluntary patients, to other hospitals, although there is every reason to suppose that such admissions must have been extremely rare. In any 
event it is probably safest to regard the admission rates shown in Table $I$ as minimum estimates.

\section{TABLE I}

MENTAL HOSPITAL ADMISSIONS, 1949-1954

\begin{tabular}{c|c|c|c|c|c|c}
\hline Year & $\begin{array}{c}\text { Esti- } \\
\text { mated } \\
\text { Popu- } \\
\text { lation }\end{array}$ & $\begin{array}{c}\text { Actual } \\
\text { Admis- } \\
\text { sions }\end{array}$ & $\begin{array}{c}\text { Rate } \\
\text { per } \\
1,000\end{array}$ & $\begin{array}{c}\text { “Ex- } \\
\text { pected" } \\
\text { Admis- } \\
\text { sions }\end{array}$ & $\begin{array}{c}\text { "Expected" } \\
\text { Rate per } \\
1,000\end{array}$ & $\begin{array}{c}\text { Ratio of } \\
\text { Actual } \\
\text { to } \\
\text { Expected" }\end{array}$ \\
\hline 1949 & 4,987 & 8 & $1 \cdot 60$ & $4 \cdot 60$ & 0.92 & $1 \cdot 74: 1$ \\
1950 & 8,814 & 10 & $1 \cdot 13$ & $8 \cdot 11$ & 0.92 & $1 \cdot 23: 1$ \\
1951 & 14,639 & 20 & $1 \cdot 37$ & $14 \cdot 28$ & 0.975 & $1 \cdot 40: 1$ \\
1952 & 16,909 & 25 & 1.48 & $17 \cdot 29$ & 1.02 & $1.44: 1$ \\
1953 & 17,256 & 33 & 1.91 & $19 \cdot 10$ & $1 \cdot 11$ & $1 \cdot 72: 1$ \\
1954 & 17,506 & 33 & $1 \cdot 89$ & $*$ & $*$ & \\
\hline
\end{tabular}

- Information not available

We have used the reports of the Registrar General based on records maintained in all mental hospitals in England and Wales to calculate "expected" admission rates for the estate for the years 1949, 1950, and 1951 (Registrar General, 1953, 1955) and have drawn on the preliminary calculations of national admission rates-as yet unpublished-for 1952 and 1953. The national age- and sex-specific mental hospital admission rates for each of the 5 years were applied to the estate population figures for the corresponding year. As Table I shows, the actual admission rate was from 23 to 74 per cent. in excess of the expected rate in each of the 5 years, and over the whole period the actual number of admissions was in excess of the expected number by slightly more than 50 per cent. The use of Greater London mental hospital admission rates as a standard, rather than the rates for the country as a whole, does not materially affect this conclusion.

Table II shows that the greater part of the excess is located in a particular age/sex group. In Table II

TABLE II

AVERAGE ANNUAL MENTAL HOSPITAL ADMISSION RATES, 1949-1954

\begin{tabular}{|c|c|c|c|c|c|c|c|c|}
\hline \multirow[t]{2}{*}{$\begin{array}{c}\text { Age } \\
\text { Group }\end{array}$} & \multicolumn{2}{|c|}{$\begin{array}{c}\text { Average Size } \\
\text { of Age } \\
\text { Group }\end{array}$} & \multicolumn{2}{|c|}{$\begin{array}{c}\text { Total } \\
\text { Admissions }\end{array}$} & \multicolumn{2}{|c|}{$\begin{array}{c}\text { Average } \\
\text { Annual Ad- } \\
\text { mission Rate } \\
\text { per } 1,000\end{array}$} & \multicolumn{2}{|c|}{$\begin{array}{c}\text { National } \\
\text { Admission } \\
\text { Rate per } \\
1,000 \text { 1951 }\end{array}$} \\
\hline & Male & $\begin{array}{c}\text { Fe- } \\
\text { male }\end{array}$ & Male & $\begin{array}{c}\mathrm{Fe}- \\
\text { male }\end{array}$ & Male & $\begin{array}{c}\text { Fe- } \\
\text { male }\end{array}$ & Male & $\underset{\text { male }}{\mathrm{Fe}}$ \\
\hline $\begin{array}{c}0-15 \\
16-19 \\
20-24 \\
25-34 \\
35-44 \\
45-54 \\
55-64 \\
65+\end{array}$ & $\begin{array}{r}2,714 \\
328 \\
226 \\
1,110 \\
1,191 \\
520 \\
157 \\
186\end{array}$ & \begin{tabular}{|r|}
2,806 \\
394 \\
429 \\
1,269 \\
1,122 \\
469 \\
177 \\
254 \\
\end{tabular} & $\begin{array}{r}3 \\
2 \\
2 \\
15 \\
17 \\
6 \\
4 \\
5\end{array}$ & $\begin{array}{l}\frac{1}{4} \\
18 \\
11 \\
18 \\
11 \\
12\end{array}$ & $\begin{array}{l}0 \cdot 18 \\
1.00 \\
1.46 \\
2.25 \\
2.38 \\
1.92 \\
4.27 \\
4.46\end{array}$ & \begin{tabular}{|r|}
0.06 \\
0.00 \\
1.56 \\
2.36 \\
1.63 \\
6.40 \\
10.34 \\
7.87 \\
\end{tabular} & $\begin{array}{l}0.06 \\
0.68 \\
1.36 \\
1.64 \\
1.32 \\
1.37 \\
1.71 \\
2.31\end{array}$ & $\begin{array}{l}0.04 \\
0.73 \\
1.26 \\
1.72 \\
1.91 \\
2.14 \\
2.22 \\
2.69\end{array}$ \\
\hline Total & 6,432 & 6,920 & 54 & 75 & 1.40 & 1.81 & $1 \cdot 16$ & 1.53 \\
\hline
\end{tabular}

we have tried to estimate the average annual ageand sex-specific admission rates for the estate over the whole period. In all the adult groups the rates are higher than would be expected on the national basis, but the discrepancy is more marked among those aged $55+$ and most strikingly marked among women aged $45+$. Middle-aged and elderly people account for only a very small proportion of the estate population, but for an entirely disproportionate number of mental hospital admissions. Not too much weight can be attached to this Table alone, since the estimates of the size of the age groups are based on the assumption that the age structure of the estate has remained constant throughout its growth. If this were untenable and the majority of people of middle age and above had settled on the estate in its earliest days, their degree of exposure to risk would have been higher and the increased average admission rates shown in this Table might be no more than a reflection of this. An essentially similar pattern emerges, however, when we calculate admission rates for those single years of the estate's history in which the age distribution is known. Females aged 45 and above account for 55 per cent. of all female admissions during the 6 year period. This corresponds fairly closely with their proportionate representation among all female admissions to mental hospital in England and Wales. But whereas this age group makes up 37 per cent. of the total female population in the country it accounts for only 13 per cent. of all females living on the estate.

The distribution of diagnoses among estate admissions (Table III, overleaf) differs significantly from the national pattern, with psychoses making up a smaller proportion of the total in both sexes.

In 1951, for example, just under 16 per cent. of all admissions to mental hospitals in England and Wales carried a diagnosis of psychoneurosis, while among the estate patients the proportion was twice as high. If the distribution as between psychoses, psychoneuroses, and other diagnoses is compared with the distribution found in national admission statistics, the difference is significant for both sexes $(P<0.01)$ and is most marked for females. The striking feature of Table III is, of course, the large number of female cases admitted with diagnoses of neurotic depressive reaction. These outnumber the males in the ratio of $3.5: 1$ as compared with the national ratio of $1 \cdot 7: 1$. That only a low proportion of the admissions were chronically ill is indicated by the high discharge rate and the short duration of hospitalization among those discharged. Of the 129 patients in question, six died in hospital and fifteen were still resident when the records were examined in 
mid-1955. The remaining 108 had left hospital and 76 of them (70 per cent.) had left within 3 months of admission.

TABLE III

DIAGNOSES ON ADMISSION: MENTAL HOSPITAL ADMISSIONS, 1949-1954

\begin{tabular}{|c|c|c|c|c|c|c|c|}
\hline & \multirow{3}{*}{ Diagnosis } & \multicolumn{6}{|c|}{ No. of Cases } \\
\hline & & \multicolumn{2}{|c|}{ Male } & \multicolumn{2}{|c|}{ Female } & \multicolumn{2}{|c|}{ Total } \\
\hline & & No. & $\begin{array}{c}\text { Per } \\
\text { cent. }\end{array}$ & No. & $\begin{array}{c}\text { Per } \\
\text { cent. }\end{array}$ & No. & $\begin{array}{c}\text { Per } \\
\text { cent. }\end{array}$ \\
\hline \multirow[t]{2}{*}{ Psychosis } & $\begin{array}{l}\text { Schizophrenia .. } \\
\text { Manic-depressive } \\
\text { Reaction } \\
\text { Senile Psychosis } \\
\text { All Other Psy- } \\
\text { choses .. } \\
\text {.. }\end{array}$ & $\begin{array}{r}14 \\
12 \\
1 \\
6\end{array}$ & & $\begin{array}{r}17 \\
13 \\
5 \\
8\end{array}$ & & $\begin{array}{r}31 \\
25 \\
6 \\
14\end{array}$ & \\
\hline & All Psychoses & 33 & (61) & 43 & (57) & 76 & (59) \\
\hline \multirow[t]{2}{*}{$\begin{array}{l}\text { Psycho- } \\
\text { neurosis }\end{array}$} & $\begin{array}{l}\text { Anxiety Reaction } \\
\text { Neurotic Depres- } \\
\text { sive Reaction } \\
\text { Other Psycho- } \\
\text { neuroses }\end{array}$ & $\begin{array}{l}5 \\
6 \\
5\end{array}$ & & $\begin{array}{r}4 \\
21 \\
1\end{array}$ & & $\begin{array}{r}9 \\
27 \\
6\end{array}$ & \\
\hline & $\begin{array}{l}\text { All Psycho- } \\
\text { neuroses }\end{array}$ & 16 & (30) & 26 & (35) & 42 & (32) \\
\hline $\begin{array}{l}\text { Behaviour, } \\
\text { Intelligenc }\end{array}$ & $\begin{array}{c}\text { Character, and } \\
\text { ce Disorders }\end{array}$ & 4 & (7) & 6 & (8) & 10 & (8) \\
\hline Other. . & $\cdots$ & 1 & (2) & - & & 1 & (1) \\
\hline Total. . & .. & 54 & & 75 & & 129 & \\
\hline
\end{tabular}

\section{Referrals to Psychiatric Out-Patient Clinics}

Referrals to psychiatric out-patient clinics are dealt with very briefly, partly because our records are unlikely to be complete, and partly because of the difficulty of finding an adequate comparison group. The available records, relating to referrals to local out-patient clinics from 1952 to 1954 inclusive, show that 133 new cases were referred from the area. The annual distribution of these cases and the corresponding referral rates per 1,000 population are shown in Table IV.

TABLE IV

PSYCHIATRIC OUT-PATIENT REFERRALS, 1952-1954

\begin{tabular}{c|c|c|c}
\hline Year & $\begin{array}{c}\text { Estimated } \\
\text { Population }\end{array}$ & $\begin{array}{c}\text { No. of } \\
\text { Referrals }\end{array}$ & $\begin{array}{c}\text { Rate per } \\
1,000\end{array}$ \\
\hline 1952 & 16,909 & 42 & $2 \cdot 5$ \\
1953 & 17,256 & 50 & $\begin{array}{r}2 \cdot 9 \\
1954\end{array}$ \\
\hline
\end{tabular}

It seems quite likely, however, that some patients may have been referred to out-patient clinics at other hospitals, especially at the London teaching hospitals; no complete record of these is available though the number was probably not very great. The annual reports of the Ministry of Health show that, for the years in question, between 100,000 and 120,000 new cases were referred each year to psychiatric out-patient clinics in England and Wales, referral rates (per 1,000 population) being $2 \cdot 5$ in 1952 and 1953 and $2 \cdot 7$ in 1954 . On the face of it these figures are very similar to the estate referral rates, but we do not know to what extent the latter rates are underestimated, nor are we in a position to standardize the rates so as to make allowance for the distinctive age structure of the estate population. The estate's use of psychiatric services was about twice as high as that of the neighbouring areas served by the same hospitals, but no great weight can be attached to this. One might anticipate that the use of hospitals outside the immediate locality would be at least as frequent among the residents of nearby districts as among people living on the estate, and in the case of psychiatric problems it may well be a good deal more common.

\section{General Practitioner Consultations}

During 1953 all the doctors in general practice on the estate maintained records of all their consultations. Details of the system of records and of the method of analysis were given by Brotherston and Chave (1956). In this section we present some of the material extracted from an analysis of the records relating to a one in four sample of families. The diagnoses listed in Table V (opposite) fall into three main categories: the psychoses and psycho-neuroses; a group of physical conditions whose aetiology is usually believed to include a substantial psychological component (this list is necessarily selective and does not include all the disorders which have at one time or another been classified as psycho-somatic); and a number of symptomatic and ill-defined conditions in which a psychological element seems often to be implicated. An attempt is made in Table $V$ to compare the frequency of these conditions in the estate population with a national standard. Since general practitioners' records based on a random or representative sample are not available, the standard must necessarily be imperfect. We have used what we believe to be the best approximation to the experience of the general population, namely that represented by the averages of the practices studied by Logan $(1953,1955)$ over a period of 3 years.

The averages for the general population shown in Table $V$ are based upon the experience of 26 practiceyears. A direct comparison with the estate population is of limited value, since the two populations differ in their age structure. We have therefore applied age- and sex-specific consultation rates prepared by 
TABLE V

GENERAL PRACTITIONER CONSULTATIONS RELATED TO CERTAIN DIAGNOSES: ACTUAL AND "EXPECTED" RATES

\begin{tabular}{|c|c|c|c|c|}
\hline \multirow{3}{*}{$\begin{array}{l}\text { No. in } \\
\text { Inter- } \\
\text { national } \\
\text { Classifi- } \\
\text { cation }\end{array}$} & \multirow{3}{*}{ Diagnosis } & \multicolumn{3}{|c|}{$\begin{array}{l}\text { No. of Patients Consulting } \\
\text { per } 1,000 \text { Registered Population }\end{array}$} \\
\hline & & \multicolumn{2}{|c|}{ Estate Population } & \multirow{2}{*}{$\begin{array}{c}\text { General } \\
\text { Populationf }\end{array}$} \\
\hline & & Actual & Expected* & \\
\hline $300-309$ & Psychosis .. & $3 \cdot 0$ & $1 \cdot 0$ & $1 \cdot 5$ \\
\hline $\begin{array}{l}310 \\
311 \\
318 \cdot 3 \\
318 \cdot 5 \\
312-317 \\
318 \cdot 0, \cdot 1 \\
\cdot 2, \cdot 4\end{array}$ & $\begin{array}{l}\text { Anxiety Neurosis } \\
\text { Hysterical Neurosis } \\
\text { Neurasthenia } \\
\text { Psychoneurosis .. } \\
\text { N.O.S. } \\
\text { Other Neuroses .. }\end{array}$ & $\begin{array}{r}23 \cdot 4 \\
1 \cdot 6 \\
13 \cdot 2 \\
11 \cdot 3 \\
6 \cdot 8\end{array}$ & $\begin{array}{r}11 \cdot 8 \\
1.4 \\
10 \cdot 3 \\
10 \cdot 6 \\
5 \cdot 4\end{array}$ & $\begin{array}{l}14 \cdot 9 \\
1.6 \\
12 \cdot 2 \\
13 \cdot 7 \\
.6 \cdot 9\end{array}$ \\
\hline $\begin{array}{l}325 \\
322 \\
320,321- \\
324,326\end{array}$ & \begin{tabular}{ll}
\multicolumn{3}{l}{ Mental Deficiency } \\
Alcoholism & .. \\
Personality & Disorders
\end{tabular} & $\begin{array}{l}\frac{0 \cdot 3}{2 \cdot 7} \\
2 \cdot 7\end{array}$ & $\begin{array}{l}1 \cdot 1 \\
0 \cdot 2 \\
3 \cdot 8\end{array}$ & $\begin{array}{l}0 \cdot 9 \\
0 \cdot 3 \\
2 \cdot 6\end{array}$ \\
\hline $\begin{array}{l}240 \\
243\end{array}$ & Hay Fever & $6 \cdot 5$ & $4 \cdot 6$ & $4 \cdot 6$ \\
\hline $\begin{array}{l}354 \\
420 \cdot 1 \\
444 \\
540 \\
541 \\
544 \\
241\end{array}$ & 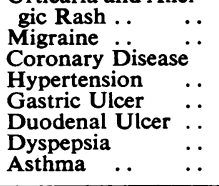 & $\begin{array}{r}24 \cdot 8 \\
8 \cdot 6 \\
1 \cdot 1 \\
6 \cdot 5 \\
4 \cdot 6 \\
10 \cdot 2 \\
18 \cdot 1 \\
12 \cdot 1\end{array}$ & $\begin{array}{r}19 \cdot 5 \\
6 \cdot 2 \\
1 \cdot 4 \\
6 \cdot 8 \\
4 \cdot 4 \\
3 \cdot 9 \\
18 \cdot 9 \\
7 \cdot 6\end{array}$ & $\begin{array}{r}14 \cdot 9 \\
6 \cdot 9 \\
3 \cdot 2 \\
15 \cdot 3 \\
6 \cdot 2 \\
5 \cdot 2 \\
23 \cdot 5 \\
8 \cdot 4\end{array}$ \\
\hline $\begin{array}{l}780 \cdot 6 \\
780 \cdot 7\end{array}$ & $\begin{array}{l}\text { Vertigo } \ldots \\
\text { Disturbances of }\end{array}$ & & & $4 \cdot 5$ \\
\hline $\begin{array}{l}782 \cdot 1 \\
784 \cdot 0 \\
786 \cdot 2\end{array}$ & $\begin{array}{l}\text { Palpitations } \\
\text { Anorexia ... } \\
\text { Incontinence of }\end{array}$ & $\begin{array}{r}25.6 \\
1.1 \\
9.7\end{array}$ & $\begin{array}{l}0 \cdot 3 \\
0 \cdot 2 \\
2 \cdot 1\end{array}$ & $\begin{array}{l}9.4 \\
0.3 \\
1.9\end{array}$ \\
\hline $\begin{array}{l}790 \cdot 0 \\
790 \cdot 1\end{array}$ & Nervousness & $3 \cdot 2$ & 0.9 & 0.8 \\
\hline $790 \cdot 2$ & "Fatigue "Depressed", $\quad$ " & 50 & 13 & $13 \cdot 2$ \\
\hline 791 & $\begin{array}{l}\text { Depression } \\
\text { Headache.. }\end{array}$ & 29.6 & 10.0 & $\begin{array}{r}4 \cdot 6 \\
11 \cdot 1\end{array}$ \\
\hline
\end{tabular}

* If rates were the same as for the general population (see text) + Derived from the Report of the Registrar General for England and Wales $(1953,1955)$.

Logan for the Registrar General to the estate population to give the expected number of patients consulting. The estate consultation rate exceeds the expected figure for psychoses, for all the neuroses, for most of the psycho-somatic disorders, and for all the symptomatic conditions. The exceptions are mental deficiency, alcoholism, personality disorders, coronary disease, hypertension, and dyspepsia. There is, however, a wide variation between the practices studied by Logan, and we assume that some part of this variation must be due to differences in diagnostic practice as well as to true differences in the incidence of illness in the different areas. We have therefore calculated the number of practiceyears in which the rates recorded for each of these conditions in the general population exceeds the estate rate. For three conditions (anorexia, debility, and headache) consultation rates in the estate practice are higher than any recorded for the general population, and for four other conditions, including duodenal ulcer, they are higher than all but one.

Table VI shows the trend with age of the consultation rate for psychoses and psychoneuroses separately for males and females. The consultation rate for females is higher than that for males in all but the youngest age groups. An interesting feature of Table VI is the decline in the consultation rate for women in the oldest age group as contrasted with a further increase among men. A similar pattern is evident when general practitioner consultations for all conditions are considered, and possible explanations were discussed in the earlier paper. We are also reminded that the mental hospital admission rate for women on the estate also falls away in the oldest age group while that for men continues to rise. There can be no doubt that the small number of old people living on the estate are altogether unrepresentative of their age and sex groups for the wider population.

TABLE VI

GENERAL PRACTITIONER CONSULTATIONS RELATED TO DIAGNOSES OF PSYCHOSIS AND PSYCHONEUROSIS

\begin{tabular}{|c|c|c|c|c|}
\hline \multirow[t]{2}{*}{$\underset{\text { (yrs) }}{\text { Age Group }}$} & \multicolumn{2}{|c|}{$\begin{array}{c}\text { No. in Sample } \\
\text { (average registered } \\
\text { population) }\end{array}$} & \multicolumn{2}{|c|}{$\begin{array}{c}\text { No. of Patients } \\
\text { Consulting per } 1,000 \\
\text { Average Registered } \\
\text { Population }\end{array}$} \\
\hline & Male & Female & Male & Female \\
\hline $\begin{array}{c}\text { Under } 20 \\
20-24 \\
25-34 \\
35-44 \\
45-54 \\
55-64 \\
65+\end{array}$ & $\begin{array}{r}842 \\
59 \\
317 \\
328 \\
147 \\
44 \\
51\end{array}$ & $\begin{array}{r}880 \\
112 \\
357 \\
324 \\
130 \\
50 \\
69\end{array}$ & $\begin{array}{l}13 \cdot 1 \\
17 \cdot 0 \\
53 \cdot 6 \\
64 \cdot 0 \\
40 \cdot 8 \\
45 \cdot 5 \\
78 \cdot 5\end{array}$ & $\begin{array}{r}11 \cdot 4 \\
80.4 \\
140 \cdot 1 \\
123.6 \\
154 \cdot 0 \\
180.0 \\
86.9\end{array}$ \\
\hline All Ages & 1,788 & 1,922 & $34 \cdot 7$ & $74 \cdot 9$ \\
\hline
\end{tabular}

For some of the other diagnostic categories numbers are too small to justify a combined analysis of incidence by age and sex. Table VII (overleaf), however, shows male and female consultation rates for all but the smallest diagnostic groups. With the exception of peptic ulcer, which is not commonly found among women, and dyspepsia, which has a slight male excess, the female consultation rate is higher for every condition.

\section{Self-RePorted Symptoms}

Between May, 1954, and February, 1955, a Family Health Survey was carried out on the estate. A sample of about $\mathbf{7 5 0}$ families was selected and their members invited to volunteer information about their own health, their use of the health services, and some general social characteristics. Each adult was 
TABLE VII

GENERAL PRACTITIONER CONSULTATIONS FOR SELECTED CONDITIONS, BY SEX

\begin{tabular}{|c|c|c|c|c|}
\hline \multicolumn{3}{|l|}{ Diagnosis } & \multicolumn{2}{|c|}{$\begin{array}{l}\text { No. of Patients Consulting } \\
\text { per 1,000 Average Registered } \\
\text { Population }\end{array}$} \\
\hline & & & Males & Females \\
\hline $\begin{array}{l}\text { Anxiety Neurosis } \\
\text { Neurasthenia } \\
\text { Psychoneurosis N.O. } \\
\text { Other Psychoses and }\end{array}$ & $\begin{array}{l}\ldots \\
\ddot{0} \\
\text { Neuroses }\end{array}$ & $\begin{array}{l}. \\
\cdots \\
\cdots\end{array}$ & $\begin{array}{r}13 \cdot 4 \\
6 \cdot 2 \\
8 \cdot 9 \\
6 \cdot 2\end{array}$ & $\begin{array}{r}32 \cdot 8 \\
19 \cdot 8 \\
13 \cdot 5 \\
8 \cdot 3\end{array}$ \\
\hline 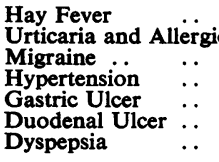 & $\begin{array}{c}\text { Rash } \\
\ldots \\
\ldots \\
\ldots \\
\ldots \\
\ldots\end{array}$ & $\begin{array}{l}\ldots \\
\because \\
\cdots \\
\cdots \\
\cdots \\
\cdots\end{array}$ & $\begin{array}{r}5 \cdot 0 \\
22 \cdot 9 \\
5 \cdot 0 \\
3 \cdot 4 \\
7 \cdot 3 \\
16 \cdot 8 \\
21 \cdot 3\end{array}$ & $\begin{array}{r}7 \cdot 8 \\
26 \cdot 5 \\
12 \cdot 0 \\
7 \cdot 8 \\
2 \cdot 1 \\
4 \cdot 2 \\
15 \cdot 1\end{array}$ \\
\hline 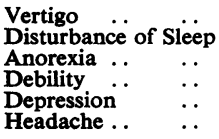 & $\begin{array}{l}. \\
\because \\
\cdots \\
\cdots \\
.\end{array}$ & $\begin{array}{l}. \\
\because \\
\because \\
\cdots \\
.\end{array}$ & $\begin{array}{r}4 \cdot 5 \\
17.9 \\
7 \cdot 8 \\
31 \cdot 3 \\
2 \cdot 8 \\
16 \cdot 2\end{array}$ & $\begin{array}{l}6 \cdot 2 \\
32 \cdot 8 \\
11 \cdot 4 \\
69 \cdot 2 \\
10 \cdot 9 \\
42 \cdot 1\end{array}$ \\
\hline
\end{tabular}

interviewed individually on at least two occasions and in the course of the first interview was presented with a check-list of forty symptoms (41 for women) and asked whether he was troubled by or subject to any of them. We consider here those symptoms which are especially relevant in the present context, namely depression, "nerves", sleeplessness, and undue irritability. 22 per cent. of all the adult subjects claimed that they were troubled by "nerves", and 17 per cent. by depression; 12 per cent, complained of sleeplessness, and almost as many of undue irritability. These percentages are not additive, since many complained of two or more of these symptoms. The total number reporting at least one of the four symptoms amounts to 35 per cent. of the entire sample; one-quarter of the men and more than twofifths of the women fall into this category.

The distribution of these complaints in relation to the age and sex composition of the sample studied is shown in Table VIII. For three of the four symptoms the female incidence is about twice as high as the male incidence. The sexes differ, however, not only in frequency of complaint but also in their patterns of age incidence. On the whole the male pattern is less clearly defined. Among the men there is a relatively high level of complaint in the age group 20-24, although the numbers here are small, and then there is a falling off between the ages of 25 and 44 ; after 45 there is a rise, but not a very steep one. Complaints of "nerves" are most frequent among men in the age group $65+$; this trend is not found in the incidence of depression or undue irritability. Complaints of sleeplessness in the oldest age group are no more common than among young men aged between 20 and 24 . In general, the degree of variation associated with age is not very great among men. Among the women, however, the frequency of complaint of each of these symptoms increases almost without exception with age, until age 64, after which there is a marked decline. There is also for each symptom a different point on the age scale at which the incidence of complaint rises with particular steepness. Thus the incidence of both "nerves" and undue irritability is at least doubled after the age of 24; the major increase in the incidence of depression is 10 years later; complaints of sleeplessness rise steeply in the mid-forties. In spite of these variations, the symptoms have two features in common, an excess of female complainants and a lower incidence among women aged $65+$ than in the age group just below it, which reflect the pattern that we have already seen in both mental hospital admissions and general practitioner consultations for psychoneurotic illness.

Since we are not aware of any other inquiry directly comparable with our Family Health Survey in scope and method, it is difficult to find an adequate standard by which to judge whether the frequency of these symptoms is exceptionally high. Probably the

TABLE VIII

FREQUENCY OF CERTAIN SYMPTOMS IN A FAMILY HEALTH SURVEY

\begin{tabular}{|c|c|c|c|c|c|c|c|c|c|c|}
\hline \multirow{3}{*}{ Age Group (yrs) } & \multirow{2}{*}{\multicolumn{2}{|c|}{ No. in Sample }} & \multicolumn{8}{|c|}{ Percentage Complaining of: } \\
\hline & & & \multicolumn{2}{|c|}{ Depression } & \multicolumn{2}{|c|}{ "Nerves" } & \multicolumn{2}{|c|}{ Sleeplessness } & \multicolumn{2}{|c|}{ Irritability } \\
\hline & Male & Female & Male & Female & Male & Female & Male & Female & Male & Female \\
\hline $\begin{array}{c}\text { Under } 20 \\
20-24 \\
25-34 \\
35-44 \\
45-54 \\
55-64 \\
65 \text { and Over }\end{array}$ & $\begin{array}{r}60 \\
42 \\
185 \\
243 \\
112 \\
27 \\
33\end{array}$ & $\begin{array}{r}85 \\
51 \\
229 \\
231 \\
102 \\
37 \\
48\end{array}$ & $\begin{array}{r}8 \\
12 \\
10 \\
9 \\
13 \\
15 \\
12\end{array}$ & $\begin{array}{r}9 \\
18 \\
19 \\
30 \\
32 \\
38 \\
19\end{array}$ & $\begin{array}{l}15 \\
19 \\
13 \\
14 \\
18 \\
15 \\
24\end{array}$ & $\begin{array}{l}12 \\
12 \\
30 \\
35 \\
29 \\
41 \\
27\end{array}$ & $\begin{array}{r}0 \\
12 \\
6 \\
7 \\
10 \\
7 \\
12\end{array}$ & $\begin{array}{r}0 \\
8 \\
12 \\
14 \\
31 \\
38 \\
31\end{array}$ & $\begin{array}{r}7 \\
12 \\
10 \\
10 \\
13 \\
0 \\
3\end{array}$ & $\begin{array}{r}4 \\
8 \\
16 \\
13 \\
15 \\
16 \\
6\end{array}$ \\
\hline All Ages & 702 & 783 & 10 & 24 & 15 & 29 & 7 & 16 & 10 & 12 \\
\hline
\end{tabular}


nearest approach to an adequate control can be found in the work of the officially-sponsored Survey of Sickness, carried out on a nation-wide basis by the Ministry (later Central Office) of Information at regular intervals over a number of years. Stocks (1949) gives a prevalence rate for psychoneuroses of 126 per 1,000 population. Survey of Sickness returns are based entirely on self-reported conditions, and this particular figure, so far as can be judged, indicates the number of persons complaining of "nerves" and possibly some other symptoms. Probably the most conservative comparison would be between Stocks's prevalence rate and the frequency with which complaints of "nerves" are reported in our Family Health Survey. Our estimate (223 per 1,000 adult population) is 77 per cent. in excess of the national rate. The comparison is not entirely satisfactory, since no allowance is made for differences in age structure. In view of the relative youth of the estate population a rate significantly below the national level would be expected. We may assume, therefore, that the true difference is if anything minimized by the present comparison.

The men and women on the estate who complain of symptoms suggestive of some degree of psychoneurotic impairment can be shown to differ in many respects, both medical and social, from their neighbours who report other or no symptoms. Most of these differences, however, are not relevant to a discussion of incidence, with one exception which is of particular interest in this context. Table IX shows the relationship between the frequency with which these symptoms are reported and the length of time the men and women concerned had been living on the estate. Complaints were most numerous among those who had come to live on the housing estate during the year or two preceding the survey. For the other two groups - those rehoused 3-4 years or 5-6 years before - the frequencies were exactly or almost exactly the same. The possible significance of this finding is discussed in the following section.

\section{TABLE IX}

INCIDENCE OF CERTAIN SYMPTOMS IN RELATION TO DURATION OF RESIDENCE ON THE HOUSING ESTATE

\begin{tabular}{c|c|c|c|c|c}
\hline \multirow{2}{*}{$\begin{array}{c}\text { Year } \\
\text { Rehoused }\end{array}$} & No. in & \multicolumn{4}{|c}{ Percentage Complaining of: } \\
\cline { 3 - 6 } & Sample & $\begin{array}{c}\text { De- } \\
\text { pression }\end{array}$ & "Nerves" & $\begin{array}{c}\text { Sleepless- } \\
\text { ness }\end{array}$ & $\begin{array}{c}\text { Undue } \\
\text { Irritability }\end{array}$ \\
\hline $1948-49$ & 538 & 16 & 21 & 12 & 11 \\
$1950-51$ & 730 & 16 & 23 & 11 & 11 \\
$1952-54$ & 219 & 23 & 25 & 15 & 15 \\
\hline
\end{tabular}

\section{Discussion}

It may well be impossible to establish a single criterion by which the mental health of an individual may be assessed, and the mental health of a community certainly cannot be measured by any absolute standard. While, therefore, we appreciate that our indices of mental ill-health are necessarily crude, it does not seem unreasonable to believe that, by bringing a number of such indices together, we may obtain an approximate assessment of the mental health status of the community with which we are concerned. Of the four measures examined, three suggested that mental health problems are significantly more common on the estate than might be expected on demographic grounds. The rate of referral to psychiatric out-patient clinics corresponds quite closely with the national average, but the likelihood of our records being incomplete, combined with the existence of substantial local differences in facilities and in referral practices, make it impossible for us to say more than that the referral rate is not lower than the national average.

The characteristics of the rehoused population do not seem to provide an adequate explanation for the apparent excess of psychological disorder among people on the estate. It is true that mental and nervous illness ranks high in the list of medical conditions for which housing priority was given, but only a small proportion of the population is affected. A medical certificate with a psychiatric or quasipsychiatric diagnosis was submitted in support of an application for rehousing, for only 2 per cent. of the adult males and 8 per cent. of the adult females. Even if we consider these figures as representing net additions to a population group in which mental and nervous disorders are otherwise normally distributed they account for only a small part of the excess incidence. It seems likely that the effects of rehousing and the conditions of life on the estate must be held responsible for the greater part of the relatively high level of neurosis.

There seem to be two principal groups of factors involved. We have first to consider the dislocating effects of the rehousing process itself, with all that it requires in the way of modification of personal and family life. The adaptation of families rehoused from overcrowded conditions in Paddington, North Kensington, and Fulham, to life on an estate of suburban character in semi-rural surroundings must necessarily be a gradual process. We know from other evidence gathered on the estate that rehousing affects very many aspects of family life. Patterns of expenditure, of employment, of leisure activities, and of relations with neighbours, kinsfolk, and friends, 
are all substantially modified. We might confidently predict, on the basis of established knowledge of the effects of social and cultural change, that the process of adaptation would be accompanied by an increase in the incidence of minor psychoneurotic and psychosomatic disorders. But we must also remember that the long-term conditions of life on the estate, with its attenuation of ties of kinship and with each family "keeping itself to itself",* may generate a degree of loneliness and social isolation inconsistent with positive mental health. The relative weight to be attached to each of these two groups of factors will depend to some extent on trends over time; a decline in the incidence of neurosis will tend to incriminate the short-term effects of rehousing as the principal factor.

An analysis of the statistics of juvenile delinquency and of the use of the child guidance services, not included in the present report, has suggested that psychological maladjustment was exceptionally common among children on the estate immediately after rehousing, but that a large measure of stabilization later occurred. Any similar trends in adults might be expected to become apparent more slowly. The mental hospital admissions do not show any consistent downward trend-though we do not yet know what an investigation over a more extended period might reveal-and our other sources of information cover only a limited period. We can, however, consider the symptoms reported in the Family Health Survey in relation to the duration of our informants' residence on the housing estate, and such an analysis points clearly to a maximum incidence of psychoneurotic symptoms among those most recently rehoused. There are therefore some grounds for anticipating a gradual improvement in the mental health status of the community.

We are aware that in this study we can merely point to certain possible connexions between the incidence of neurosis on the estate and some of the social characteristics of the community; we cannot rigorously demonstrate a causal relationship. In this type of investigation the unit of study is in a sense the

* A recently published study of another L.C.C. housing estate provides a perceptive analysis of this problem (Young and Willmott, 1957). entire community, and in that sense we have only a single case. From that point of view we should welcome comparable studies of other communities, and especially of housing estates, New Towns, and extended towns. Studies of mental health problems in New Towns, whose principle of social development is substantially different from that of housing estates, would be especially illuminating.

\section{SUMMARY}

A relatively high incidence of psychological disorder in the population of a new housing estate is indicated by an analysis of the use of general practitioner and psychiatric out-patient services, mental hospital admissions, and the results of a personal interview survey. It is suggested that this high incidence may be attributable in part to the effects of rehousing and to the conditions of social life on the estate. There are, however, some indications of a gradual amelioration with time.

We are deeply indebted to Dr. J. H. Patterson, Physician Superintendent of Napsbury Hospital, for permission to study his records, to the general practitioners of the estate for their assiduous record-keeping, to Miss Ann Cartwright for her work in connexion with the Family Health Survey, to Miss Jane Cooper for her work on the analysis of the records, to Miss E. M. Brooke of the General Register Office for very kindly supplying in advance of publication the statistics of mental hospital admissions for 1952 and 1953, and to Prof. J. M. Mackintosh for his constant encouragement of the project of which this report forms part.

\section{REFERENCES}

Brotherston, J. H. F., and Chave, S. P. W. (1956). British Journal of Preventive and Social Medicine, 10, 200.

Logan, W. P. D. (1953). “General Practitioners' Records". Studies on Medical and Population Subjects, No. 7. General Register Office. H.M.S.O., London.

(1955)." "General Practitioners' Records". (In continuation of Study No. 7). Ibid., No. 9. General Register Office. H.M.S.O.,
London.

Maule, H. G., and Martin, F. M. (1956). Advance. Sci., 12, 443, 448.

Registrar General (1953). "Statistical Review of England and Wales

for 1949: Supplement on General Morbidity, Cancer, and Mental Health". H.M.S.O., London.

(1955). Ibid for 1950-51. H.M.S.O., London.

Stocks, P. (1949). "Sickness in the Population of England and Wales in 1944-1947; . Studies on Medical and Population Subjects, No. 2. General Register Office. H.M.S.O., London.

Young, M., and Willmott, P. (1957). "Family and Kinship in East London". Routledge and Kegan Paul, London. 